\title{
The Anaerobic Metabolism of Glucose and Fructose by Saccharomyces bailii
}

\author{
By W. EMMERICH AND F. RADLER* \\ Institut für Mikrobiologie und Weinforschung der Johannes Gutenberg-Universität Mainz, \\ Postfach 3980, D-6500 Mainz, Federal Republic of Germany
}

(Received 6 April 1983; revised 27 May 1983)

In contrast to most yeasts, which ferment glucose more rapidly than fructose, Saccharomyces bailii ferments fructose first, then glucose. Thus, in a medium containing fructose and glucose, diauxic growth results. Cells of $S$. bailii that were grown on fructose were unable to ferment glucose when suspended in a glucose-containing buffer solution. Fructose-grown cells were cryptic for glucose fermentation but contained the enzymes for glucose metabolism. When suspended for $2 \mathrm{~h}$ in a growth medium containing glucose, fructose-grown cells acquired the ability to ferment glucose, due to the synthesis of a carrier protein. This induction was prevented by cycloheximide. In $S$. bailii, fructose was transported into the cells by a constitutive carrier system that was insensitive to uranyl ions. The inducible glucose carrier system was completely inhibited by $10^{-4} \mathrm{M}$-uranyl ions. If subsequent metabolism of hexoses was inhibited by iodoacetic acid, the uptake of hexoses could be measured by the increase in their intracellular concentrations. Fructose-grown cells took up only fructose whereas glucose-grown cells possessed an inducible glucose carrier and uptake of both glucose and fructose was observed. A model is proposed to explain the sequential fermentation of fructose and glucose in $S$. bailii.

\section{INTRODUCTION}

Dubrunfaut (1847) and Bourquelot (1886) observed that the hexoses glucose and fructose were metabolized at different rates during alcoholic fermentation. Most yeasts, including the typical wine yeasts, ferment glucose more rapidly than fructose (glucophilic yeasts) whereas a few yeasts belonging to the species Saccharomyces rouxii and Saccharomyces bailii ferment fructose preferentially (fructophilic yeasts) (Peynaud \& Domercq, 1955). The glucophilic characteristic of yeasts was explained by the nature of their system of hexose transport. The metabolism of both sugars was similar, except for glucose 6-phosphate which is an intermediate of glucose metabolism only. Gottschalk (1946) regarded the preference of glucose as being due to the permeability of the cell membrane. Sols (1956) assumed that both sugars are transported by the same carrier but that fructophilic yeasts have a higher affinity for fructose.

The differential fermentation of glucose and fructose is of some interest for the wine industry, because the glucose : fructose ratio in the unfermented residual sugar can be used to detect an addition of saccharose or grape must to wine after fermentation. Furthermore, fructose has a much sweeter taste than glucose, which can be of advantage for some wines. In this paper, the fermentation of glucose and fructose by Saccharomyces cerevisiae and S. bailii, in growing and in resting cells is described. By determining the activity of the primary enzymes of the metabolism of glucose and fructose, it should be possible to determine whether the fermentation of these hexoses is regulated at the level of such enzymes. The inducible nature of the glucose fermentation was also investigated.

\section{METHODS}

Organisms and culture conditions. Saccharomyces bailii, strain N2120 (obtained from Dr F. E. M. J. Sand, Bussum, Netherlands) and Saccharomyces cerevisiae strain 43 from the collection of this institute were used. The 
yeasts were cultivated on the synthetic B-medium (Heerde \& Radler, 1978), and the carbon source varied as required. Cultures grown in $5 \mathrm{ml} \mathrm{B}$-medium at $28^{\circ} \mathrm{C}$ for $24 \mathrm{~h}$ were used to inoculate $50 \mathrm{ml}$ of the same medium. This procedure was repeated until final cultures of 0.2-2 1 were obtained. Experimental cultures were grown for $36 \mathrm{~h}$ at $28^{\circ} \mathrm{C}$ in shaken Erlenmeyer flasks fitted with fermentation traps.

Preparation of glucose-grown cells, fructose-grown cells, glycerol-grown cells and cell extracts of $S$. bailii. Cultures were grown anaerobically as described in B-medium containing $10 \%(\mathrm{w} / \mathrm{v})$ glucose or $10 \%(\mathrm{w} / \mathrm{v})$ fructose respectively. Glycerol-grown cells were cultured on $5 \mathrm{~g}$ glycerol (l B-medium) $)^{-1}$ with aeration. After $24 \mathrm{~h}$ at $28^{\circ} \mathrm{C}$, the cells were collected by centrifugation and washed twice in $0 \cdot 1 \mathrm{M}-\mathrm{KCl} / \mathrm{HCl}$ buffer, $\mathrm{pH} 3 \cdot 1$. Cell extracts were prepared by maceration with glass beads as described by Kuczynski \& Radler (1982).

Measurement of hexose uptake. Cells of $S$. bailii were suspended in the above buffer $\left[10 \mathrm{ml}\left(\mathrm{g}\right.\right.$ wet weight) $\left.{ }^{-1}\right]$ and incubated at $30^{\circ} \mathrm{C}$ in $200 \mathrm{ml}$ Erlenmeyer flasks gassed with $\mathrm{N}_{2}$ for $10 \mathrm{~min}$ on a water-bath shaker. Samples $(2 \mathrm{ml})$ of this suspension were centrifuged for $1 \mathrm{~min}$ at $3000 \mathrm{~g}$. To the sediment was added $5 \mathrm{ml}$ ice-cold $10 \%(\mathrm{w} / \mathrm{v})$ hexose solution in $\mathrm{KCl} / \mathrm{HCl}$ buffer containing $1 \mathrm{~mm}$-iodoacetic acid. After intensive shaking for $5 \mathrm{~s}$, the suspension was transferred to screw-cap bottles and gassed with $\mathrm{N}_{2}$ for $3 \mathrm{~min}$. The bottles were incubated in a water-bath shaker at $30^{\circ} \mathrm{C}$ and the reaction was stopped by immersing the bottles in an ice-bath. The cells were rapidly recovered by filtration on membrane filters $(0.45 \mu \mathrm{m}$ pore size) and rinsed three times with $5 \mathrm{ml}$ ice-cold $\mathrm{KCl} / \mathrm{HCl}$ buffer. After weighing, the cells were extracted in $1 \mathrm{ml}$ absolute ethanol for $1 \mathrm{~h}$. Water $(2 \mathrm{ml})$ was added, before the cells were removed by centrifuging and the hexoses determined in the supernatant. The intracellular concentration of glucose and fructose was calculated by assuming that the composition of yeast cells is $67 \%$ water and $33 \%$ dry matter.

Analytical determinations. D-Glucose and D-fructose-were determined enzymically with hexokinase, glucose-6phosphate dehydrogenase (Bergmeyer et al., 1974) and additional phosphoglucose isomerase for fructose (Bernt \& Bergmeyer, 1974). Protein was determined using the Biuret method, or the spectrophotometric method of Warburg \& Christian (1941). The cell mass was determined either by weighing on the membrane filter or photometrically (Zeiss PM 6) by measuring the turbidity at $610 \mathrm{~nm}$ and comparing with a calibration curve of a known cell suspension. The production of $\mathrm{CO}_{2}$ was measured manometrically with a Warburg apparatus.

Enzyme determinations. Hexokinase was determined spectrophotometrically at $340 \mathrm{~nm}$, with the substrates glucose or fructose according to Bergmeyer et al. (1974). For the determination of glucosephosphate isomerase, fructose-1,6-bisphosphate aldolase and 6-phosphofructokinase the procedures described by Conrad \& Schlegel (1977) were used. One unit (U) is the enzyme activity that converts $1 \mu \mathrm{mol}$ substrate min $^{-1}$. Specific activities are $\mathrm{U}$ (mg protein) $)^{-1}$.

Chemicals. All enzymes and co-enzymes were purchased from Boehringer-Mannheim. Cycloheximide was obtained from Serva, and the other chemicals were from Merck.

\section{RESULTS}

A preliminary experiment confirmed that $S$. cerevisiae used glucose and fructose simultaneously when grown on a mixture of these sugars (Fig. 1a). Glucose was used more rapidly than fructose, so that the ratio of glucose to fructose changed during fermentation in favour of fructose. When $S$. bailii was grown under identical conditions, only fructose was metabolized and the concentration of glucose was not significantly changed during the growth (Fig. $1 b$ ). This striking difference in the utilization of sugars could be caused either by differences in the transport systems or by the subsequent intracellular metabolism of the sugars. At a total sugar concentration of less than $10 \%$, curves showing diauxic growth were observed with $S$. bailii. During the first growth phase, fructose was consumed, then after a short 'lag' period, glucose was fermented during a second phase of growth.

To determine whether the presence of fructose prevented the metabolism of glucose, $S$. bailii was grown in a medium containing glucose or fructose as the only fermentable sugar. Such cells are termed glucose-cells or fructose-cells, respectively. Washed, resting glucose-cells $(50 \mathrm{mg})$ suspended in $\mathrm{KCl} / \mathrm{HCl}$ buffer $(2.9 \mathrm{ml})$ fermented glucose, fructose and mannose producing 9.5 , 38.4 and $21.6 \mu \mathrm{mol} \mathrm{CO} \mathrm{CO}_{2} \mathrm{~h}^{-1}$, respectively. The concentration of each sugar was $20 \mathrm{mM}$. Fructose-cells fermented fructose at the same rate as glucose-cells $\left(37 \cdot 3 \mu \mathrm{mol} \mathrm{CO}_{2} \mathrm{~h}^{-1}\right)$, but glucose was not fermented at all. Similar observations were made with cells grown aerobically on glycerol (glycerol-cells). Such cells behaved like fructose-cells: fructose was fermented, glucose was not. Thus it was shown that glucose-cells and fructose-cells were different and that the presence of fructose was not essential to prevent the metabolism of glucose.

If fructose-cells and glucose-cells of $S$. bailii that were originally grown from the same 

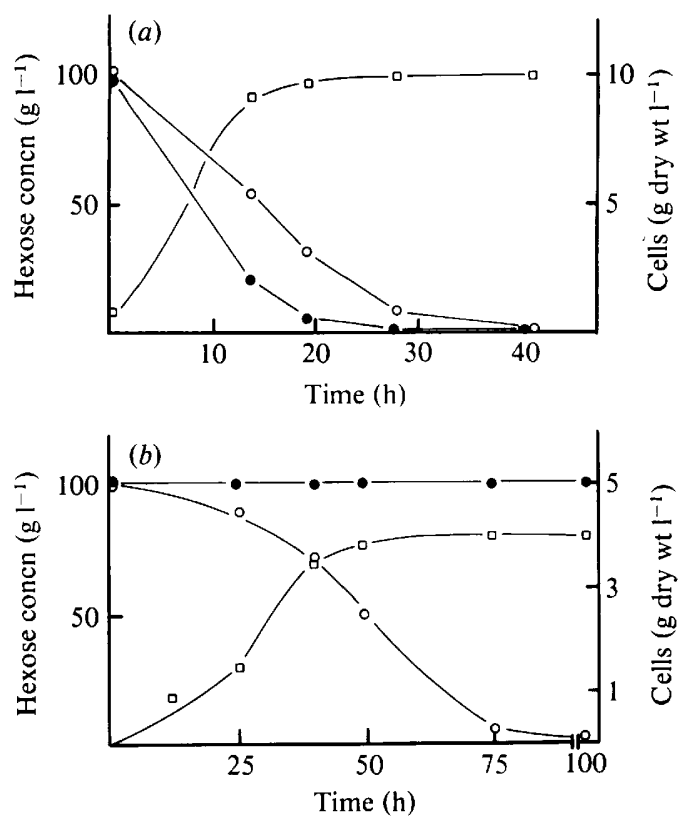

Fig. 1. Fermentation of glucose $(O)$ and fructose $(O)$ by growing cultures of $(a) S$. cerevisiae and $(b) S$. bailii. Growth ( $\square$ ) was in B-medium, pH 3.2, containing $100 \mathrm{~g}$ glucose and $100 \mathrm{~g}$ fructose $1^{-1}$ at $27^{\circ} \mathrm{C}$ in shaken fermentation vessels.

inoculum showed such different abilities to ferment sugars, the most likely basis would be the phenomenon of induction. In fact, glycerol-cells, initially unable to ferment glucose, acquired this ability within $2 \mathrm{~h}$ by incubation in a complete medium that contained glucose (Fig. 2). This induction was dependent on protein synthesis, since glycerol-cells incubated in glucose-medium plus cycloheximide did not acquire the capacity to ferment glucose. This new protein(s) could be either an enzyme involved in hexose metabolism or a protein that catalyses the transport of glucose. To investigate the first possibility, the activities of the enzymes involved in the metabolism of glucose or fructose were determined in fructose-cells and in glucose-cells.

The activities of various enzymes were determined in cell extracts of glucose-cells, fructosecells, and glycerol-cells of $S$. bailii (Table 1). As expected, there were quantitative differences in the enzyme activities. However, all cells contained hexokinase that phosphorylated glucose and fructose. This enzyme (hexokinase) of which at least three isoenzymes exist (Gancedo et al., 1977), was found to be very similar in $S$. bailii and $S$. cerevisiae (W. Emmerich, unpublished results). Although a special glucokinase is known in yeast, this activity is associated with fructokinase and was found in glucose-cells and in fructose-cells of $S$. bailii. The yeast cells always contained hexokinase and not a separate and different glucokinase or fructokinase. Furthermore, the important enzyme glucose phosphate isomerase, which is involved in the metabolism of glucose only (Fig. 3), was present in fructose-cells and in glucose-cells. Thus there was no evidence that the metabolism of glucose and fructose in $S$. bailii was regulated at the level of the repression of catabolic enzymes. Therefore, it was assumed that the sugar metabolism of $S$. bailii is controlled at the level of membrane transport.

By measuring the production of $\mathrm{CO}_{2}$ by glucose- and fructose-cells, the apparent substrate affinities for the fermentation of glucose and fructose were determined. Glucose-cells showed a low apparent affinity for glucose $\left(K_{\mathrm{m}}=80 \mathrm{~mm}\right)$ and a much higher affinity for fructose $\left(K_{\mathrm{m}}=20 \mathrm{~mm}\right)$. Fructose-cells showed a similar apparent substrate affinity for fructose $\left(K_{\mathrm{m}}=25 \mathrm{mM}\right)$ as did glucose-cells. Fructose-cells did not produce $\mathrm{CO}_{2}$ from glucose.

The existence of two separate mechanisms for the uptake of glucose or fructose was further demonstrated by the effect of uranyl nitrate. This compound is known to inhibit hexose 


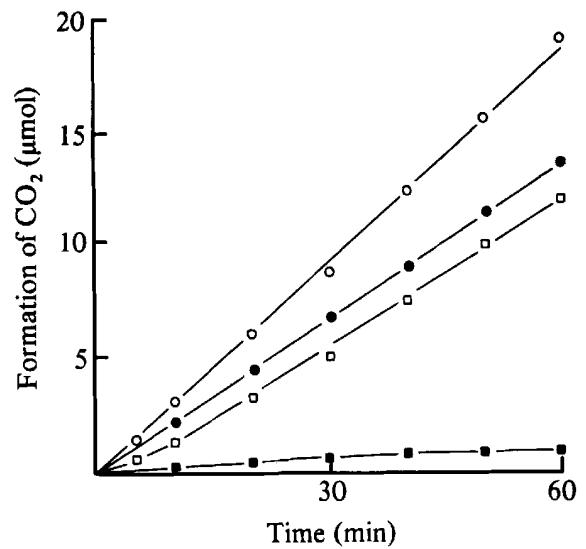

Fig. 2. Induction of the glucose-metabolizing system in glycerol-cells of $S$. bailii. Glycerol-cells were suspended in B-medium with $10 \%$ glucose (open symbols) or in B-medium with $10 \%$ glucose and $10^{-3} \mathrm{M}$-cycloheximide (filled symbols) for $2 \mathrm{~h}$. The cells were then washed and the formation of $\mathrm{CO}_{2}$ from the sugars fructose $(O, O)$ and glucose $(\square, \square)$ was determined manometrically.

Table 1. Activities of enzymes of carbohydrate metabolism in cell extracts of $S$. bailii grown on different carbon sources

\begin{tabular}{lccc} 
Enzyme & \multicolumn{3}{c}{$\begin{array}{c}\text { Specific activity }\left(\mathrm{U} \mathrm{mg}^{-1}\right) \\
\text { with carbon source: }\end{array}$} \\
\cline { 2 - 4 } Glucose & Fructose & Glycerol \\
Phosphoglucose isomerase & 0.31 & 0.12 & 1.09 \\
Fructose-1,6-bisphosphate-aldolase & 0.04 & 0.002 & 0.21 \\
6-Phosphofructokinase & 0.05 & 0.10 & $0 \cdot 13$ \\
Hexokinase (glucose) & 0.42 & 0.36 & ND \\
Hexokinase (fructose) & 0.65 & 0.48 & ND
\end{tabular}

ND, Not determined.

transport in yeast (Kotyk \& Michaljanicova, 1968). The metabolism of fructose was very insensitive to uranyl nitrate; even at $10^{-2} \mathrm{M}$ the formation of $\mathrm{CO}_{2}$ from fructose by fructose-cells or glucose-cells of $S$. bailii was only inhibited by about $30 \%$ (Table 2). Fructose-cells did not metabolize glucose. In glucose-cells, glucose metabolism was very sensitive to uranyl ions and $10^{-4} \mathrm{M}$-uranyl nitrate inhibited the formation of $\mathrm{CO}_{2}$ from glucose completely. Thus two different mechanisms or carrier systems exist for the uptake of glucose and fructose in $S$. bailii, one was resistant, and the other very sensitive to uranyl ions.

This observation was confirmed in a further experiment, in which the production of $\mathrm{CO}_{2}$ from glucose by glucose-cells of $S$. bailii was measured in the presence of uranyl nitrate (Fig. 4). If uranyl nitrate was present from the beginning, no $\mathrm{CO}_{2}$ was produced. If the inhibitor was added to glucose-fermenting cells after $20 \mathrm{~min}$, the formation of $\mathrm{CO}_{2}$ stopped immediately. However, these cells were not inactivated or destroyed, for if fructose was added, the substrate was fermented. $\mathrm{CO}_{2}$ is, of course, the final product of hexose metabolism. However, it is generally assumed that because of the high substrate and catabolite affinities of the glycolytic enzymes, membrane transport is the limiting reaction that controls the rate of formation of $\mathrm{CO}_{2}(\mathrm{Becker} \&$ Betz, 1972; Barnett \& Sims, 1976b; Höfer, 1977).

Because of the rapid metabolism of hexoses and other substrates, their intracellular concentration is generally very small in yeast cells. In order to measure the anaerobic uptake of hexoses 
Glycolysis

Hexose monophosphate

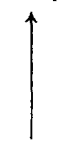

Glucose phosphate isomerase

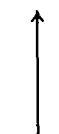

Fructose-1,6-bisphosphate

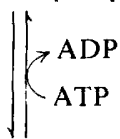

Glucose 6-phosphate

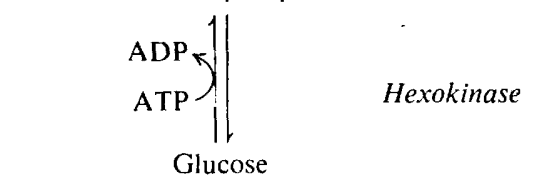

Fructose 6-phosphate

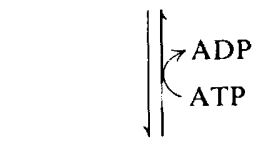

Fructose

Inside

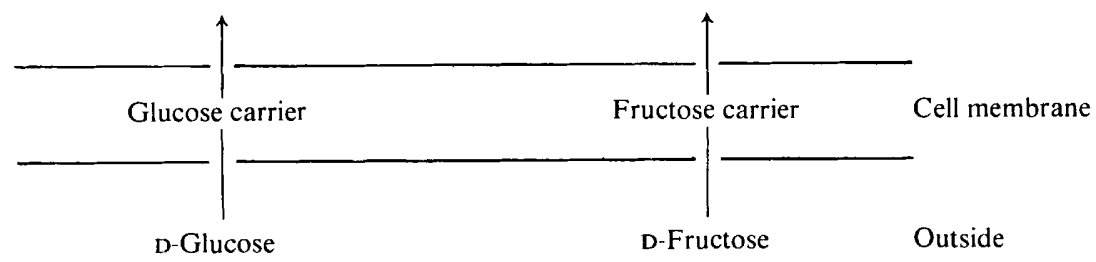

Fig. 3. Pathway of glucose and fructose metabolism in yeast.

Table 2. Inhibition by uranyl nitrate of hexose fermentation by $S$. bailii

$\begin{array}{cccccccc}\begin{array}{c}\text { Carbon source } \\ \text { in growth } \\ \text { medium }\end{array} & \begin{array}{c}\text { Substrate for } \\ \text { fermentation }\end{array} & \overbrace{10^{-1}} & 10^{-2} & 10^{-3} & 10^{-4} & 5 \times 10^{-5} & 0 \\ \text { Glucose } & \text { Glucose } & 100 & 100 & 100 & 96 & 46 & 0 \\ & \text { Fructose } & 57 & 32 & 26 & 2 & 0 & 0 \\ \text { Fructose } & \text { Glucose } & - & - & - & - & - & - \\ & \text { Fructose } & \text { ND } & 31 & \text { ND } & \text { ND } & \text { ND } & 0\end{array}$

ND, Not determined.

- , No $\mathrm{CO}_{2}$ formation.

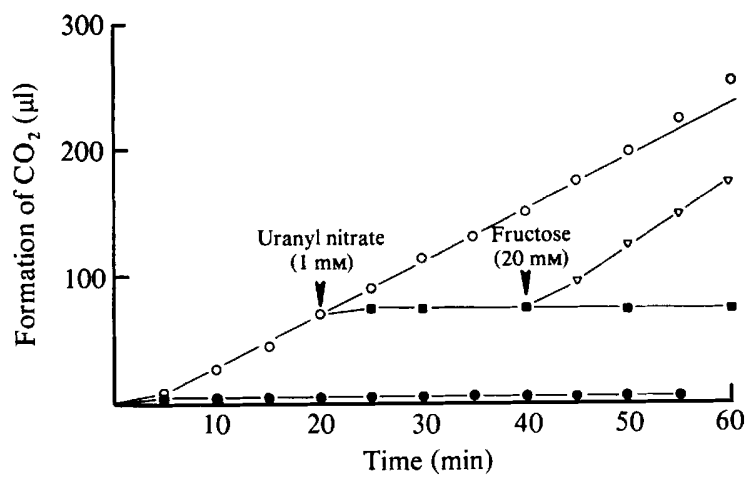

Fig. 4. Inhibition of the anaerobic metabolism of glucose of resting cells of $S$. bailii by uranyl nitrate. Glucose-cells $(50 \mathrm{mg})$ were suspended in $2.9 \mathrm{ml} \mathrm{KCl} / \mathrm{HCl}$ buffer $(0.1 \mathrm{M}, \mathrm{pH} 3 \cdot 1)$ with $60 \mu \mathrm{mol}$ glucose $(O)$, and $1 \mathrm{mM}$-uranyl nitrate was added at the start $(\Theta)$ or when indicated by the arrow $(\square)$. Fructose $(20 \mathrm{mM})$ was added when indicated by the arrow to cells previously inhibited by uranyl nitrate $(\nabla)$. 


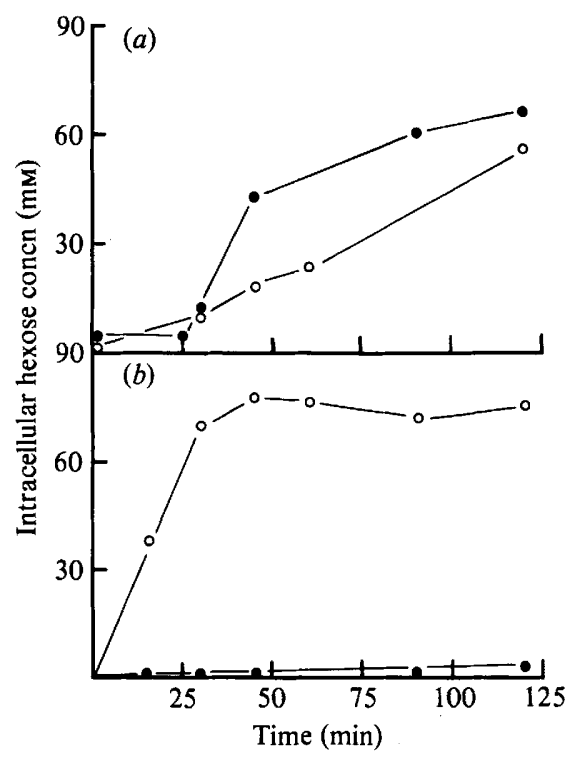

Fig. 5. Transport of glucose (O) or fructose $(O)$ by $(a)$ glucose-cells or $(b)$ fructose-cells of $S$. bailii in the presence of $1 \mathrm{~mm}$-iodoacetic acid under $\mathrm{N}_{2}$.

by yeast cells, their metabolism has to be inhibited without interfering with the transport system. For this purpose several investigators (Holzer et al., 1955; Cirillo, 1962; van Steveninck, 1969) have used iodoacetic acid successfully. Preliminary experiments with $S$. bailii have shown that hexose metabolism, as measured by production of $\mathrm{CO}_{2}$, was completely inhibited by $10^{-3} \mathrm{M}$ iodoacetic acid. Thus it was possible to measure the uptake of hexoses by determining their intracellular concentration in the yeast cells directly, provided that the transport itself was not inhibited by iodoacetic acid. Fructose-cells took up fructose only (Fig. 5); glucose was not found intracellularly. When glucose-cells were exposed to glucose or fructose, the intracellular concentration of both sugars increased. Similar experiments with cells of $S$. cerevisiae showed no significant difference in the uptake of glucose or fructose.

\section{DISCUSSION}

In contrast to $S$. cerevisiae, a yeast that ferments glucose and fructose simultaneously (although at different rates), the fermentation of glucose in $S$. bailii depends on the presence of an inducible system. However, although all strains of $S$. bailii tested fermented fructose preferentially, differences in the degree of fructose preference were observed.

Analysis of the activity of glycolytic enzymes failed to correlate the preferential fructose fermentation with differences in the enzyme spectrum. Neither a kinase specific for glucose (glucokinase) nor differences in the activity of glucose phosphate isomerase were observed in glucose-cells or fructose-cells of $S$. bailii. A special study of the hexokinase of $S$. bailii and $S$. cerevisiae (results not described in this paper) revealed that both organisms contained three hexokinases with a different ratio of phosphorylation of glucose and fructose. However, our results with $S$. bailii were very similar to the observations of Sols (1956) and of Gancedo et al. (1977) with $S$. cerevisiae.

Fructose-cells of $S$. bailii can be called cryptic with respect to their metabolism. Crypticity was regarded as being due to the absence of a transport system (Barnett, 1976). The transport of fermentable hexoses can be determined directly by measuring their intracellular concentration in the presence of a metabolic inhibitor that prevents the catabolism of hexoses (Kotyk \& Janacek, 1975; Höfer, 1977; Sols, 1968). Since both hexoses were taken up by iodoacetic acid- 
inhibited glucose-cells it was assumed that glucose and fructose were transported by facilitated diffusion independent of metabolic energy. This was originally shown for $S$. cerevisiae by Burger et al. (1959) and recently confirmed by Romano (1982). If the transport is rate-limiting (Becker \& Betz, 1972; Barnett \& Sims, 1976a) then the substrate affinity of the hexose carrier can be determined indirectly by measuring the products of hexose metabolism. Our experiments showed that cell extracts of $S$. bailii induced to catabolize glucose do not contain glucose or glucose 6-phosphate. This indicates that the metabolism was much more rapid than the influx of glucose.

The apparent $K_{\mathrm{m}}$ values for fructose fermentation in $S$. bailii $\left(K_{\mathrm{m}}=20 \mathrm{~mm}\right)$ were very similar to those reported by Kotyk (1967) and Cirillo (1968) for fructose transport in $S$. cerevisiae. The apparent $K_{\mathrm{m}}$ values for glucose fermentation of glucose-cells of $S$. bailii were about 15-16 times higher than those found by Kotyk (1967) for glucose transport in $S$. cerevisiae.

Besides the transport system described in this paper a further regulatory mechanism has been observed that will be briefly mentioned. If glucose-cells of $S$. bailii were suspended in a buffer solution containing fructose, their ability to metabolize glucose was rapidly diminished and completely lost after $2 \mathrm{~h}$. This inactivation was independent of the presence of cycloheximide. A similar observation has been described for the transport of galactose in $S$. cerevisiae (Alonso \& Kotyk, 1978). This de-induction was explained by the activation of a protein-decomposing system by energy-providing substrates.

The results presented in this paper do not give an explanation for the biological significance of the preferential fructose fermentation of $S$. bailii. It may be that this characteristic is linked to the osmotolerance of these yeasts (Tilbury, 1980).

This research was supported in part by a grant from the Forschungsring des Deutschen Weinbaus. We thank Dr M. Höfer, Bonn for his valuable suggestions.

\section{REFERENCES}

Alonso, A. \& KotYK, A. (1978). Apparent half-lives of sugar transport proteins in Saccharomyces cerevisiae. Folia microbiologica 23, 118-125.

BARNETT, J. A. (1976). The utilization of sugars by yeast. Advances in Carbohydrate Chemistry 32, 125 234.

BARNeTt, J. A. \& Sims, A. P. (1976a). Some physiological observations on the starving and exponentially-growing yeast. Archives of Microbiology 111, 185-192.

BarnetT, J. A. \& Sims, A. P. (1976b). A note on the kinetics of uptake of D-glucose by the food yeast, Candida utilis. Archives of Microbiology 111, 193-194.

BECKER, J. U. \& BETZ, A. (1972). Membrane transport as controlling pacemaker of glycolysis in Saccharomyces carlsbergensis. Biochimica et biophysica acta 274, 584-597.

Bergmeyer, H. U., Bernt, E., Schmidt, F. \& Stork, H. (1974). D-Glucose: Bestimmung mit Hexokinase und Glucose-6-phosphat-Dehydrogenase. In Methoden der enzymatischen Analyse, vol. 2, pp. 1241-1246. Edited by H. U. Bergmeyer. Weinheim: Verlag Chemie.

BERNT, E. \& BERGMEYER, H. U. (1974). D-Fructose: Bestimmung mit Hexokinase, Glucose-6-phosphatDehydrogenase und Phosphoglucose-Isomerase. In Methoden der enzymatischen Analyse, vol. 2, pp. 1349-1352. Edited by H. U. Bergmeyer. Weinheim: Verlag Chemie.

BoURQUELOT, E. (1886). Recherches sur la fermentation alcoolique d'un melange de deux sucres. Annales de chimie et de physique 9, 245-275.
Burger, M., Hejmova, L. \& Kleinzeller, A. (1959). Transport of some mono- and disaccharides into yeast cells. Biochemical Journal 71, 233-242.

CrRILlo, V. P. (1962). Mechanism of glucose transport across the yeast cell membrane. Journal of Bacteriology 84, 485-491.

Cirillo, V. P. (1968). Relationship between sugar structure and competition for the sugar transport system in baker's yeast. Journal of Bacteriology 95, 603-611.

ConRad, R. \& Schlegel, H. G. (1977). Different degradation pathways for glucose and fructose in Rhodopseudomonas capsulata. Archives of Microbiology 112, 39-48.

DUBRUNFAUT, M. (1847). Sur une propriété analytique des fermentations alcoolique et lactique, et sur leur application á l'étude des sucres. Annales de chimie et de physique 3, 167-178.

Gancedo, J. M., Clifton, D. \& Fraenkel, D. G. (1977). Yeast hexokinase mutants. Journal of Biological Chemistry 252, 4443-4444.

Gottschalk, A. (1946). Mechanism of selective fermentation of D-fructose from invert sugar by Sauternes yeast. Biochemical Journal 40, 621626.

Heerde, E. \& Radler, F. (1978). Metabolism of the anaerobic formation of succinic acid by Saccharomyces cerevisiae. Archives of Microbiology 177, 269276.

HöFER, M. (1977). Transport durch biologische Membranen; Das Konzept der Trägerkatalyse. Weinheim: Verlag Chemie. 
Holzer, H., Holzer, E. \& Schulz, G. (1955). Zusammenhang zwischen Wachstum und aerober Gärung. Biochemische Zeitschrift 326, 385-404.

KotYK, A. (1967). Properties of the sugar carrier in baker's yeast. II. Specificity of transport. Folia microbiologia 12, 121-131.

KotYK, A. \& JANACEK, K. (1975). Cell Membrane Transport. New York \& London: Plenum Press.

Kotyk, A. \& Michaluanicova, D. (1968). Properties of the sugar carrier in baker's yeast. IV. An asymmetric component of monosaccharide transport. Folia microbiologica 13, 212-220.

KUCZYNSKI, J. T. \& RADLER, F. (1982). The anaerobic metabolism of malate of Saccharomyces bailii and the partial purification and characterization of malic enzyme. Archives of Microbiology 131, 266-270.

Peynaud, E. \& DomercQ, S. (1955). Sur les espèces de levures fermentant selectivement le fructose. Annales de l'Institut Pasteur 89, 346-351.

Romano, A. H. (1982). Facilitated diffusion of 6deoxy-D-glucose in baker's yeast: evidence against phosphorylation-associated transport of glucose. Journal of Bacteriology 152, 1295-1297.

Sols, A. (1956). Selective fermentation and phosphorylation of sugars by Sauternes yeast. Biochimica et biophysica acta 20, 62-68.

Sols, A. (1968). Regulation of carbohydrate transport and metabolism in yeast. In Aspects of Yeast Metabolism, pp. 47-66. Edited by A. K. Mills. Oxford \& Edinburgh: Blackwell Scientific Publications.

VAN Steveninck, J. (1969). The mechanisms of transmembrane glucose transport in yeast: evidence for phosphorylation, associated with transport. Archives of Biochemistry 130, 244-252.

TILBURY, R. H. (1980). Xerotolerant (osmophilic) yeast. In Biology and Activities of Yeast, pp. 153-179. Edited by F. A. Skinner, S. M. Passmore \& R. R. Davenport. London: Academic Press.

WARBURG, O. \& Christian, W. (1941). Isolierung und Kristallisation des Gärungsferments Enolase. Biochemische Zeitschrift 310, 384-421. 